\title{
El sirventès en la poesia catalana dels segles XIV-XV: un catàleg
}

\author{
Albert Tomàs Monsó \\ Universitat Autònoma de Barcelona \\ albert.tomas@uab.cat \\ https://orcid.org/OOOO-OOO2-I475-3973 \\ Received Io/O4/2018; accepted o8/o6/20I8 \\ DOI: https://doi.org/IO.7203/MCLM.5.12285
}

The sirventes in fourteenth- and fifteenth-century Catalan poetry: a catalogue

Abstract

The sirventes of the troubadour era has been broadly studied, but there are not overall explanations concerning the evolution of the sirventes genre in the Catalan-speaking lands of the fourteenth and fifteenth centuries. This paper propounds a catalogue of sirventesos concerning its historical development, the troubadour models, rhetorical and grammatical treatises, and genre assignment in rubrics.Our catalogue contains thirty-one Catalan sirventesos, including twenty-eight extant items and three items lost. In some cases the literary motifs of the sirventes cross boundaries in a process of poetic hybridization with other moral genres which borrow out themes, images and rhetorical strategies from the sirventes. In order to reflect this complexity, our catalogue also includes an annex with twenty-seven texts that are not properly sirventesos but, due to their idiosyncrasy, can be placed in the periphery of the genre.

\section{KEYWORDS}

Medieval Catalan poetry; sirventes; war poetry; moral poetry; maldit; troubadour poetry; rhetorical and grammatical treatises; literary genres; catalogue.

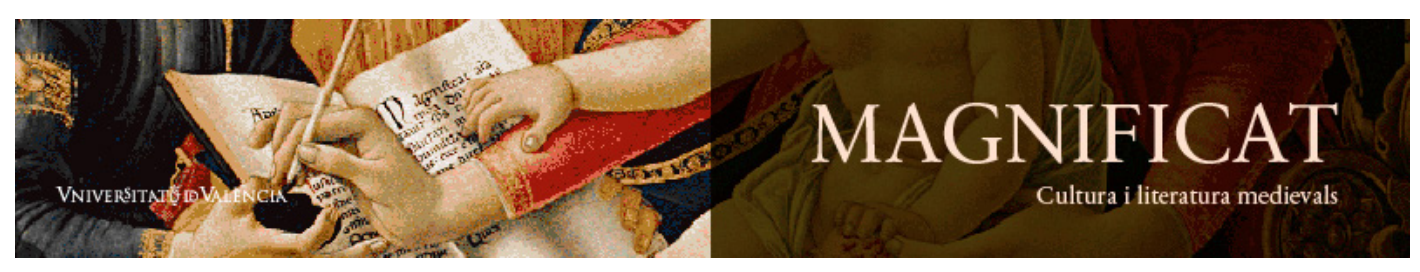

Magnificat Cultura i Literatura Medievals 5, 20I8, 7I-II4. http://ojs.uv.es/index.php/MCLM

ISSN 2386-8295 
RESUM

A diferència del que s'esdevé amb el sirventès trobadoresc, manquen aproximacions de conjunt que expliquin la continuïtat d'aquest gènere durant els segles XIV-XV als territoris de parla catalana. Aquest article presenta un catàleg de textos que permetrà una definició del gènere. Se'n consideren l'evolució històrica, els models trobadorescos, el tractament que en van fer les preceptives retòriques i gramaticals, i l’assignació de rúbriques als manuscrits. El catàleg consta de trenta-un sirventesos catalans; vint-i-vuit de conservats i tres de no conservats. En ocasions, els motius temàtics propis del sirventès traspassen les fronteres del gènere, com a resultat d'un procés d'hibridació amb els altres gèneres morals, que en manlleven temes, imatges o recursos retòrics. Per donar compte d'aquesta complexitat, el catàleg inclou un annex de vint-i-set textos que no són sirventesos però que, per la seva idiosincràsia, es troben a l'òrbita del gènere.

PARAULES CLAU

Poesia catalana medieval; sirventès; poesia bèl-lica; poesia moral; maldit; poesia trobadoresca; tractats retòrics i gramaticals; gèneres literaris; catàleg.

Albert Tomàs Monsó. 2018. 'El sirventès en la poesia catalana dels segles XIV-XV: un catàleg', Magnificat Cultura i Literatura Medievals, 5: 7 I-II4 (cc)BY

\section{TAULA DE CONTINGUTS}

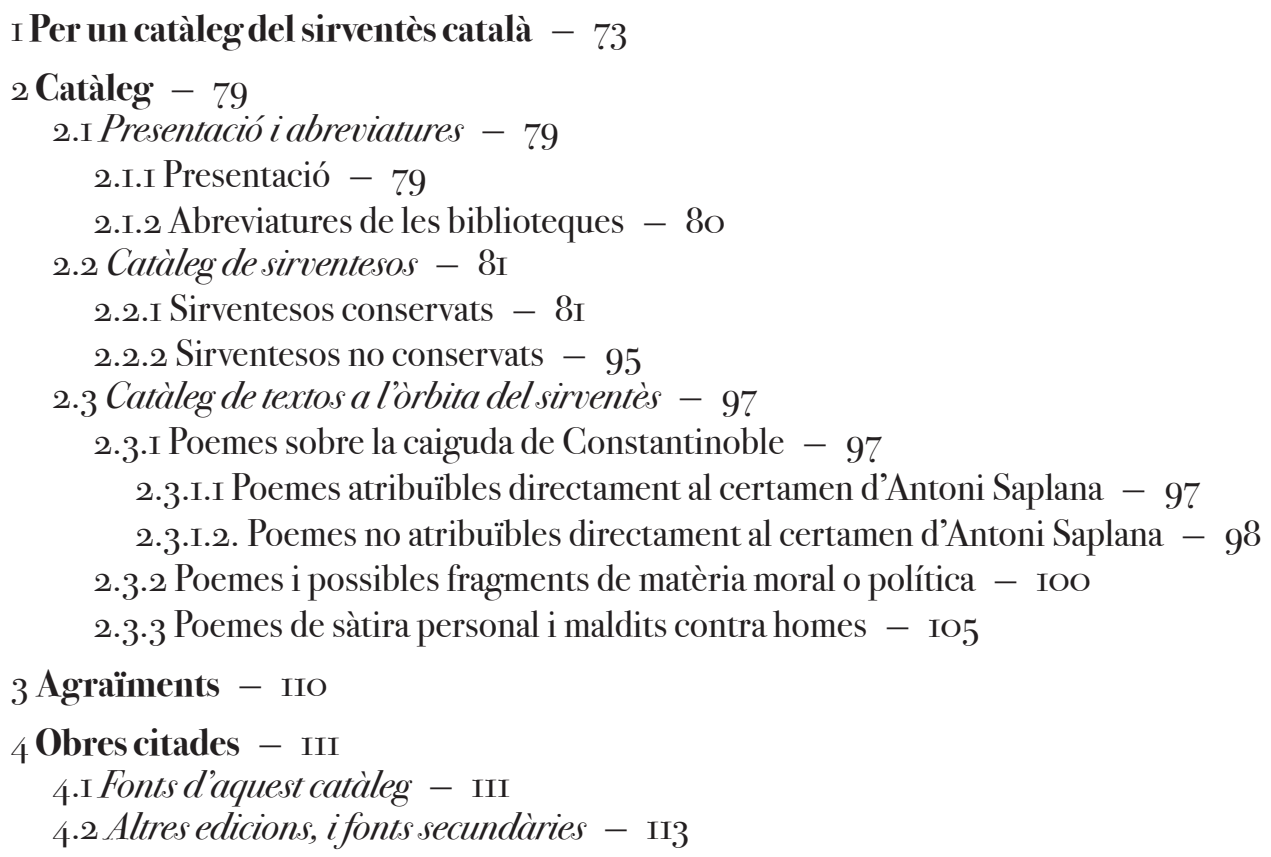




\section{ə*⿻丷木}

\section{Per un catàleg del sirventès català}

El sirventès trobadoresc ha estat definit canònicament com un tipus de poesia política i moral, amb elements de sàtira personal. Concebut en la majoria dels casos sota el prisma de l'actualitat, el sirventès té el propòsit d'influir en l'atmosfera social del moment, habitualment amb referències bèllliques i moralitzants, que poden actuar com un argument d'atac més o bé com a tema per se (Riquer 1973 i ed. 1975). Formalment, a més, és habitual que el trobador aprofiti la melodia i l'estructura mètrica d'una cançó o d'un vers conegut per tal d'assegurar la difusió ràpida i eficaç de la peça. D'altra banda, les fronteres entre els gèneres morals són poroses (Thiolier-Méjean 1973) i la bibliografia més moderna s'ha decantat per parlar d'un contínuum de gèneres, impossibles de destriar de manera precisa, que emergeixen d'una realitat mundana de la qual es fan ressò (Di Girolamo 1990). D’acord amb la idea de contínuum genèric, Paden (2000) ha perioditzat l'evolució dels gèneres trobadorescos entre ııоo i Izoo i ha alertat dels perills d'una excessiva compartimentació moderna, ja que "we cannot be sure that the canso, sirventes and cobla were distinctive concepts in the minds of troubadours or their public until at least as late as period 3 [II8O-I22O]" (Paden 2000: 32). Recentment, Stefano Asperti (2002, 2004 i 2005) ha presentat el sirventès com un discurs profà sobre els esdeveniments del món, que pot fer referència directa a un fet $\mathrm{i}$, per tant, tenir una funció pragmàtica tal com la descriuen Martí de Riquer i Constanzo Di Girolamo, o pot, per altra banda, apropar-se a una funció retòrica, epideíctica -hereva del genus demonstrativum llatí-, i tenir un component simbòlic, com la laus i la vituperatio o els elogis de la dama de la cançó, “quasi com a estructura expressiva que 'autoritza' el discurs profa d'actualitat, que li confereix la dignitat necessària, i li permet, exactament com la cançó, esdevenir vehicle d'expressió de nous valors" (Asperti 2005: 54).'

Contrastant amb l'abundosa bibliografia que s'ocupa del sirventès trobadoresc, la poesia catalana medieval no compta amb aproximacions de conjunt que expliquin la continuïtat del gènere als segles XIV i XV. L'objectiu del present article és justament contribuir a clarificar el panorama del conreu del sirventès durant aquests dos segles amb un catàleg de textos que ajudi a dibuixar-ne l'evolució històrica i a distingir els diferents temes, formes i funcions que pot adoptar. Per a la fixació del catàleg s'han tingut en compte els models trobadorescos, el tractament que en van fer les preceptives retòriques i gramaticals, i l'assignació de rúbriques als manuscrits com a indicador positiu de la concepció tardomedieval del gènere.

El catàleg que segueix consta de trenta-un sirventesos catalans, vint-i-vuit de conservats i tres

I. Per a Di Girolamo (1990: 184-85), la descoberta dels vicis socials i les debilitats del sistema feudal en la poesia en vulgar implica la possibilitat del blasme. Des d'aquesta perspectiva, la dicotomia de l'elogi i el blasme situa la poesia en un espai públic, adreçada a una audiència que ha de ser complaguda eloqüentment (Lausberg I96o: I, I3I-32). A l'antiguitat el discurs elogiós o panegíric a persona estava fortament relacionat amb el genus demonstrativum, que, segons Lausberg (I960: I, I30), no afecta directament l'espectador; aquest interpreta el discurs com una exhibició de l'oratòria. La recepció de la retòrica clàssica -també portadora d'aquesta màxima- en època medieval passa, sobretot, per les figures de Ciceró i Quintilià. Per a la laus, vid. Lausberg (196o: 2, 736); per a la vituperatio (1960: 2, 842-43). Per a la recepció de la retòrica clàssica a l'edat mitjana, vid. Murphy (1974: 89-132). A partir de l'anàlisi de la Doctrina de compondre dictats, hi ha hagut qui ha proposat que aquest tractat es basa en una "long-standing medieval practice of viewing all written texts as acts of demonstrative rhetoric in which an author or auctor uses praise and blame to commend virtue and condemn vice" (Dagenais 2000: 247), amb especial influència en la lírica occitanocatalana del segle XIV. 
de no conservats. Cinc s’inscriuen clarament en la tradició bèl-lica de Bertran de Born (I, 4, 7, $\mathbf{5}$ i I6). Catorze són de contingut polític: els dotze que conformen el cicle de Joan II $(\mathbf{2}, \mathbf{3}, \mathbf{I} 4, \mathbf{1 7}$, $\mathbf{1 8}$ i 20-25) i els perduts de Pere March (29) i el rei Pere III (3I). Tres són de contingut politicomoral: dos de Pere March (II, I3) i el de l'infant Pere, perdut (30). Vuit són sàtires de contemptu mundi (5, 9, IO, I2, I9, 26, 27 i 28) i, finalment, dos són rareses: el violent atac d'Arnau d'Erill (6) i la peça laudatòria seguint les lleis de la retòrica de Joan Ramon Ferrer (8).

L'heterogeneïtat de la pràctica poètica, però, fa que les categories siguin de mal delimitar. En ocasions, els motius temàtics propis del sirventès traspassen les fronteres del gènere, com a resultat d'un procés d'hibridació amb els altres gèneres morals, que en manlleven temes, imatges o recursos retòrics. Per donar compte d'aquesta complexitat, el catàleg inclou un annex de textos que no són sirventesos però que conformen un grup de vint-i-set poemes que orbiten al voltant del gènere. Aquest annex pot ser dividit tres grans àrees: primer, els poemes pertanyents al cicle de la caiguda de Constantinoble el I453: un total de sis, atribuïbles directament o indirecta a un certamen organitzat a Barcelona per Antoni Saplana amb aquest pretext històric, en un record de la cançó de croada; segon, un grup heterogeni de poemes de matèria política i moral, un total de deu, que basculen entre la sàtira de col-lectius, la poesia circumstancial, nascuda de la realitat política i social del moment, i la tradició del regiment de prínceps; per últim, un bloc d’onze poemes satírics de caire personal, alguns, maldits contra homes.

De l'anàlisi dels textos podem concloure que el sirventès català presenta una doble funció. D’una banda, la funció propagandística, pragmàtica, descrita per Riquer (I973) a propòsit del sirventès trobadoresc, que es manté inalterada. D’altra banda, el sirventès català també demostra la funció epideíctica identificada per Asperti (2002), que posa en qüestió de manera parcial la noció de propaganda. En els sirventesos catalans, la hipòtesi d'Asperti queda reforçada per dos elements més. En primer lloc, l'existència dels motius i imatges concrets, provinents de la tradició trobadoresca, que revelen un alt grau de codificació i, per tant, de superació de la referencialitat immediata, sense que això vagi en detriment d'una motivació real última dels textos, subjacent en la majoria dels casos. En segon lloc, la recitació pública en contextos celebratius i de certamen, com passa amb el cicle al voltant de l’infant Joan i els sirventesos de Masdovelles (I7-25), amb llargues rúbriques que contenen un flux important d'informació paratextual sobre les circumstàncies de la recitació. En altres casos, situar la poesia en l’àmbit públic porta implícit el seguiment de l'art del discurs, tal com exemplifiquen Joan Ramon Ferrer a "Com sia just, per gran manutanença” (8) i el certamen de poesia bèl-lica que presentà Felip de Malla l'any I4I3 (Pujol i996).

Si ens fixem en les línies evolutives del gènere, durant el segle XIV triomfâ el model poètic de Bertran de Born, de to elevat i mitificador de la cavalleria. Corresponen a aquest model textos que reporten fets d'actualitat amb voluntat propagandística i recullen l'exaltació bèl-lica trobadoresca, amb al-lusions a la guerra i el gust per la descripció truculenta. Un dels motius més característics de Bertran de Born és el brogit de la batalla i el carnatge. En la majoria dels casos són escenografies o paisatges bèl-lics (Asperti 2005) que es construeixen amb una fórmula visual seguida d'imatges de detall:

En brieu veirem camps joncatz de qartiers

d'elms e d'escutz e de branz e d'arços

e de fendutz per bustz tro als braiers;

es arage veirem anar destriers

e per costatz e per piechz manta lansa

(...)

trompas, tabors, seinheras e penos

e entreseinhs e cavals blancs e niers 
veirem en brieu, qe-l segles sera bos

(“Miei-sirventes vueilh fa dels reis amdos” vv. IO-I5 i I7-I9; Gouiran ed. 1985: 649-56).

El model de Bertran de Born és seguit per alguns autors catalans, com ara l'anònim de "[...] la croada" (I), Andreu Febrer a "Dolorós critz ab votz brava, terribla" (7) o Guillem de Masdovelles a "Senyor mot naut, l'autrier me ffes demanda" (I6), i “En breu veyrem torney mortal bastir" (I5), com mostren els vv. I-5: "En breu veyrem torney mortal bastir / ho seran ffayts, de mans homens, quartiers, / e caps talhats de gentils cavallhiers / e gran senyors hi convendra morir / per mortals colps, de llançes e d'estochs" (Aramon i Serra ed. I938: I89-90).

La destrucció i la presa de castells, viles i places és un altre motiu procedent de Bertran de Born i té una especial fortuna entre els autors catalans del segle XIV, com ara Guillem de Masdovelles a "Senyor mot naut, l'autrier me ffes demanda" (I6), "Viles he burchs, castells prenden per fforça" (Aramon i Serra ed. I938: I9I-92, v. 30), o Andreu Febrer a "Dolorós critz ab votz brava, terribla" (7), "intrar murs forts, torrç e castelhs per forces, / que no·s porà fer res contra nós defendre / (...) metén a fons e gitan foch e flama / viles e burchs, lochs, ciutats e mesquitas" (Riquer ed. 195I: 87-90, vv. 22-23 i 37-38). Tanquen aquesta petita llista de motius procedents de la tradició bèl-lica trobadoresca el blasme de l'enemic per malvat, traïdor i infidel, que normalment fa una ofensa imperdonable, com el robatori de les hòsties per part dels sarraïns en el sirventès d'Andreu Febrer (7), i la figura de l'enumeració, ja sigui de gestes, ja sigui de reis i nobles (“[...] la croada", I; "Tant es lo mons ples d'amor descorteza”, 4). Dels textos que es troben a l'òrbita del sirventès, però que no ho són, el que presenta més interès és el d'Huguet del Vellat "En breu veyrem una freyor abatre", que combina una reescriptura conceptual de la tradició de Bertran de Born amb imatges de l'Apocalipsi.

Encara dins l'esfera del sirventès polític, el component circumstancial del gènere es manté -com observem en el sirventès del rei Pere III a propòsit de la campanya de Sardenya (3I) - i afavoreix l'aparició de cicles poètics al voltant d'un tema, amb presa de posicions polítiques per part dels autors. És el cas del cicle de I374, descrit a les cartes de l’infant Joan (Rubió i Lluch ed. r9o8-2I: I, 252-54), que donà peu, com a mínim, a un sirventès perdut de Pere March (29), al qual l’infant assegura haver respost. És també el cas de l'extens cicle de Joan II, que segueix el fil de la guerra civil catalana de mitjans del segle XV i dels esdeveniments que la precediren. El cicle de Joan II el conformen dos sirventesos anònims contra la ciutat de Barcelona, "Pus que tothom se n'aparta" (2) i “Torbat, perdut en una vall pregona” (3), el poema de Pero Martines sobre l'alliberament de Carles de Viana (I4) i els vuit que va dedicar Joan Berenguer de Masdovelles (I7, $\mathbf{8}$ i 20-25) a les victòries reialistes. En aquests poemes, però, desapareixen les imatges truculentes i de batalla pròpies del segle XIV i resten només les referències estrictament polítiques.

També perllonga la seva existència en el temps fins com a mínim a mitjans del segle XV el model de sirventès moral, que té com a objectiu la denúncia de la decadència dels valors socials a través de la sàtira moralitzant. En aquest cas no podem parlar de motius codificats, sinó de temes vinculats a la tradició del mundus immundus que es concreten de maneres diverses. El més habitual és el menyspreu del món, amb especial predilecció pel tòpic del món capgirat, sovint utilitzat per Cerverí de Girona: "e vey los rics vils honrar / per lor mantenia, / e.ls francs dezonrar, / don me creys ir'e feunia / e ay a cantar / tal vetz que plorar deuria" ("Trop m’enug de cortz anar", Riquer ed. r947: 85-88, vv. 19-24), que va tenir un destí cèlebre en la poesia catalana. El tema, que té una formulació emblemàtica en la Cançó d'opòsits de Jordi de Sant Jordi, és reprès per Pere Tresfort (28), Ramon Savall (27), Pere March (9, Io i I2) i Pere Despuig a "Pus que bondat neç abtesa" (5), (vv. 5-8 i I3I8): 
Mant hom vey prous ez ardits,

complits de virtuts assats,

e, pus no son favorits,

valen los poch ses bondats.

(...)

Altres vey nicis e roms,

ffolls e pechs que.s fan valer;

pus favor los vol tener,

no.ls lexa may pendre toms,

ans quant fan es tot prohesa,

e les folldats, gran honor[.]

(Cabré ed. 2000a)

La permeabilitat temàtica entre el sirventès i el vers tardà ja és present en la poesia dels trobadors en què els dos gèneres sovint es confonen (Cabré 20II: 288-93; per a la funció del sirventès en l'obra de Cerverí com a instrument legitimador de Pere el Gran, Cabré 20ıг: ı86-87).

Encara en el deixant de Cerverí, el sirventès moral es tenyeix, en alguns casos, de referències politicomorals provinents de la tradició del regiment de prínceps. Aquesta ramificació del gènere no es limita a una parcel-la ètica, sinó que va més enllà i il-lustra un propòsit alliçonador i legitimador dels poders polítics establerts. La peça perduda de l'infant Pere (30), llegida amb motiu de la coronació d’Alfons el Benigne el I328 i reportada per Muntaner a la seva Crònica (Coll i Alentorn ed. 1927-54: 26-27), constitueix una exposició sobre el significat al-legòric dels atributs reials. En una definició del concepte del vassallatge feudal, el monarca posseeix els regnes a títol personal per encàrrec diví; a canvi, però, ha de regir-los amb propietat, sense perjudici, i defensar-los dels enemics. La il·lustració d'un propòsit moral de la peça de l'infant Pere està amplificada al sirventès conservat de Pere March “Tots grans senyors qui bé vol avenir” (I3). La peça, que fa parella amb "Cest qui ço fay d'on li deu seguir dan” (II), se situa en la tradició del didactisme polític i moral, i tracta sobre el recte govern i els deures del senyor (Cabré ed. I993: 70-72 i I55-60). Els poemes de Pere March i l'infant Pere responen a la introducció d'un nou enfocament, poc habitual al sirventès trobadoresc. L'origen d'aquesta nova matèria l'hem de cercar, com dèiem, en Cerverí de Girona, però també en altres trobadors de la seva generació com Giraut Riquier. Segons Miriam Cabré (2OII: 293), després del desgast de l'infant Pere els anys abans d'esdevenir rei, el sirventès va perdre prestigi per la seva condició propagandística i combativa, inapropiada per a una figura reial. "L'etapa que s'inaugura a finals de i2 76 buscarà l'ennobliment que s'associa amb el saber, i es vehicularà a través del vers, convertit en el nou vehicle de castiamen per excel-lència, en el nou mitjà per difondre la ideologia que emanava de la cort reial catalana". En aquest nou ordre de coses, Cerverí s'apropia de la figura del savi i conseller per tal de revestir-se d'autoritat moral “al mateix temps que crea la veu ideal per difondre la ideologia reial” (Cabré 2OII: 293). En dur a terme aquesta operació, "Cerverí desenvolupa una sèrie de temes que s'adiuen a aquesta figura del savi, però que també són útils per a una cort interessada en el saber, la moral i la cortesia" (Cabré 2OII: 293).

La poesia moral catalana del segle XIV manté algunes d'aquestes particularitats en el sirventès. Les referències a la batalla han desaparegut i no hi ha censura de vicis, atac personal ni lloança explícita de senyors. En el cas de Pere March, tampoc hi ha referències d'actualitat ni el valor celebratiu dels ideals feudals. Quant al contingut, doncs, els poemes només compleixen el paràmetre lax de parlar de la política i el vassallatge, tot i que ho fan com a conceptes abstractes, talment com si es tractés de vers. Més avall matisarem els conceptes de sirventès i vers a partir del 
que en diuen els tractats retòrics i gramaticals. De moment, avancem que el que diferencia aquests dos gèneres morals és que al sirventès domina l’element satíric, mentre que al vers, l'exposició d'una argumentació de caràcter alliçonador o catequètic.

Si bé el sirventès politicomoral és propi del segle XIV, amb l’infant Pere i Pere March com a grans exponents, alguns dels seus trets, com els atributs del governant, queden fossilitzats en els sirventesos polítics del segle XV que corresponen al cicle de Joan II, especialment en els de Joan Berenguer de Masdovelles, que tendeixen a enaltir les qualitats de Joan II com a regent. Algunes de les peces de Joan Berenguer de Masdovelles basen la justificació de les idees polítiques en conceptes morals i, per tant, són paradigmàtics de la fina línia que separa vers i sirventès. També ho és el poema "Tot clarament vol e mostra natura", de Joan de Castellnou, que consisteix en un argumentari moral de defensa de la croada per raó natural i divina i que està rubricat "vers".

D’altra banda, la sàtira personal característica de Guillem de Berguedà no presenta continuïtat en el sirventès català. Isabel Grifoll (2OI7) ha constatat, en la producció d'aquest trobador, una disparitat entre les composicions satíriques primerenques, de tall joglaresc, i els sirventesos posteriors, en què Guillem de Berguedà hauria estat influenciat pel model de Bertran de Born. Així, les referències personals i/o burlesques perderen pes dins d'un gènere ja cortès, portador d'uns valors ideològics determinats; s'imposà, dones, la modalitat moralitzant de denúncia de la decadència del món. Fins i tot en el cas del sirventès personal d'Arnau d'Erill “O tu, traÿdor, qui tan sovint renegues” (6), propici per a l'ús d'aquest tipus de recursos, el to del poema ha perdut les notes de comicitat i es basa en un atac ferotge sense pal-liatius. No obstant això, cal matisar, com fa Torró (ed. 2009: 66), que

... quan l'atac es particularitza en persones concretes, apareix la possibilitat de descriure la víctima en els seus detalls i individualitzar comportaments per a fer-ne burla. Si podem distingir entre sirventesos i composicions denigratòries morals, d'una banda, i poesia jocosa i burlesca o còmica, de l'altra, en la pràctica entre aquests tons extrems existeixen moltes vies, perquè la sàtira a més de castigar i atacar també havia de ridiculitzar i provocar la rialla.

D’aquest fet eren ben conscients els autors dels tractats retòrics medievals, que projectaren els seus preceptes sobre la pràctica poètica. Un total de vuit tractats gramaticals medievals recullen una definició més o menys àmplia del sirventès ${ }^{2} \mathrm{i}$, a excepció de les Regles de trobar, tots reprodueixen el mateix esquema explicatiu. D’una banda, una tesi formal: el sirventès és una poesia servil, sotmesa a un altre gènere, ja que n'aprofita l'estructura, la mètrica o la rima; de l'altra, una de contingut, menys unànime: el gènere tracta, grosso modo, de relacions de poder, fets polítics i bèl-lics d'actualitat i de reprensió de vicis mundanals.

Quant a la tesi formal, basada en el contrafactum d'un text anterior (Marshall r980), l'observació

2. Són les Regles de trobar, de Jofre de Foixà (Marshall ed. 1972: 57; Barcelona, Biblioteca de Catalunya, ms. 239), la Doctrina de compondre dictats, d'autor anònim (Marshall ed. I972: 95-97; Barcelona, Biblioteca de Catalunya, ms. 239), els anomenats Tractats de Ripoll, també d’una mà anònima (Marshall ed. I972: IO2; Barcelona, Arxiu de la Corona d’Argó, ms. 299 de Ripoll), les Leys d'amors, de Guilhem Molinier, en la primera redacció, en el manuscrit de Tolosa (Gatien-Arnoult ed. I84I-43: 340 i 354; Tolosa de Llenguadoc, Archives de l’Académie des Jeux Floraux ms. 500.0O7) i en el de Sant Cugat (Gonfroy ed. I98ı: I, I67-68 i 182; Barcelona, Arxiu de la Corona d’Aragó, ms. I3 de Sant Cugat), i en la segona redacció (Angade ed. r9ı9: 2, ı8г; Tolosa de Llenguadoc, Archives de l’Académie des Jeux Floraux, mss. 500.0o6), les Flors del Gay Saber (Anglade ed. 1926: 70; Barcelona, Biblioteca de Catalunya, ms. 239), el Doctrinal de trobar de Raimon de Cornet (Casas Homs ed. ı969: ı97; Barcelona, Biblioteca de Catalunya, ms. 239), a més del Compendi de la conaxença dels vicis que poden esdevenir en los dictatz del Gay Saber, de Joan de Castellnou (Casas Homs, ed. ı969: ı42; Barcelona, Biblioteca de Catalunya, ms. 239) i el Torcimany, de Lluís d’Averçó (Casas Homs ed. I969: 83-86; El Escorial, Biblioteca del Monasterio del Escorial ms. M. I. 3). 
directa dels textos en ordre cronològic traça una evolució molt clara. Les Regles (I289-9I) no aporten res sobre aquest aspecte. A mesura que avança el segle XIV, però, es va conformant una consciència retòrica d'arrel etimològica aplicada al sirventès. La Doctrina (finals del segle XIII) diu que el sirventès "se serveix e es sotsmes a aquell cantar de qui pren lo so e les rimes" (Marshall ed. I972: 57), sense definir, però, quin és "aquell cantar" del qual manlleva la forma. ${ }^{3}$ Els Tractats de Ripoll (I29O-I35O van un pas més enllà i diuen que "sirventesch es semblant en nombre de cobles e de refrayn a la canço" (Marshall ed. I972: IO2). No és fins a la primera redacció occitana de les Leys d'amors (1328-37) que es codifica el sirventès com a subsidiari o bé del vers o bé de la cançó: "sirventes es dictatz ques servish al may de vers o de chanso en doas cauzas. la una. cant al compas de las coblas. lautra cant al so" (Gatien-Arnoult ed., I84I-43: 340). La potència d'aquesta màxima repercuteix no només en la pràctica poètica, sinó també en la resta de tractats. Les diverses redaccions en vers i en prosa de les Leys d'amors (1328-37; I330; 1355-56), ${ }^{4}$ les Flors del Gay saber (I337-43) i el Compendi de Joan de Castellnou (I324-4I) -que segons Beatrice Fedi (2OI7) va tenir accés a una versió molt primerenca de les Leys - en són deutores i concreten la imitació en la rima. El Torcimany (finals del segle XIV), per la seva banda, amplia els patrons de servitud formal i parla de cobles, síl-labes, accent, vers i rima, tot i que no afegeix novetats importants al que ja havien dit els tractats precedents. Només el Doctrinal de Raimon de Cornet (I324) presenta algunes especificitats rellevants. ${ }^{5}$ De tots el més lacònic, posa l'accent en la tornada i el senyal, que tot bon dictat ha de tenir.

A diferència de l'explicació formal, la tesi de contingut que defensen els tractats no deriva de l'etimologia. Segons les preceptives, no hi ha connexió directa entre la servitud del vassall -el sirvent-i el terme "sirventès", fet notori, ja que això significa que aquesta concepció neix i es desenvolupa en bona mesura en la pràctica poètica, per posar un exemple clar, amb Cerverí de Girona a "Hom no pot far sirventes mas sirven". Només la Doctrina recull les dues hipòtesis etimològiques, la formal i la de contingut.

En general, el que domina en les definicions dels tractats són tres idees. La primera, que el sirventès ha de parlar de fets de guerra; les Regles fins i tot avisen de no mesclar-los amb raons d'amor. La Doctrina parla de "senyors o de vassalls", així com d'“ordenances o de novelletatz" (Marshall ed. 1972: 95) que tinguin a veure amb la guerra o amb Déu, senyal que la matèria pròpia de les cançons de croada, la guerra santa, també podia ser cantada amb sirventesos. Més concrets són els tractats de Ripoll, que esmenten afers assenyalats com ara "host", "aveniment de rey" o "preso d'alcun loch", però també "castich d'alcuna persona o per semblan cosa" (Marshall ed. I972: IO2). L'univers de les Leys d'amors, el Doctrinal i el Compendi no innoven. La segona idea relativa al contingut del gènere que recullen tots els tractats és que un sirventès pot blasmar o castigar els malvats del món, amb possibilitat de lloar els dignes i mostrar-los com a exemple (Doctrina) i d'educar els ignorants (Leys, segona redacció en prosa). La diferència del sirventès amb el vers, en aquest aspecte, pot ser tènue. No obstant això, preval una certa noció que el vers és un mitjà per a vehicular una veritat epistemològica i divina. En canvi, el Doctrinal de Raimon de Cornet afirma que el sirventès "de mals pot parlar / que vers no ho deu far" (Casas Homs ed. I969: I97). En la censura dels vicis, doncs, el sirventès té un component satíric i acusador, fet que el diferencia del vers, que

3. El primer autor que utilitza el procediment del contrafactum, Bertran de Born, que esdevé modèlic, s’inicia en el sirventès amb "Seigner En coms a blasmar", on imita la forma, precisament, d'un altre sirventès, "Eu non cuidava chantar”, de Guillem de Berguedà, i no pas d’una cançó o un vers, com recomanen els tractats posteriors.

4. La filiació i datació exacta de les diferents redaccions no generen consens entre la bibliografia. Segueixo l’aportació més o menys recent, amb voluntat de totalitzar la qüestió, de Beatrice Fedi (I999).

5. Aquesta preceptiva en vers només s'ha conservat inserida en la glossa que en va fer Joan de Castellnou (Casas Homs ed. I969). 
no reprèn els mals del món sinó que transmet un axioma moral. En tercer i últim lloc, i de manera taxativa, els tractats són portadors d'una diferenciació entre maldit general o sàtira de col-lectius, que és acceptada, i maldit especial o sàtira personal, codificada com a vici, que no distingeix entre homes i dones, fet que explica la presència de poemes de sàtira contra homes rubricats com a "maldit". Són exemples de maldit general o sàtira de col-lectius els poemes de Joan Berenguer de Masdovelles, "Estant ratret e d'enuig fatiguat" (19), i Lluís de Requesens "Ans de molt temps veureu los confessós" $\left.{ }_{\mathbf{2}} \mathbf{6}\right)$, tots dos atacs satírics contra el clergat.

De l'observació dels tractats es desprèn que el sirventès català s'inscriu en la tradició formal culta del gènere trobadoresc. Ho fa, però, de manera laxa. Els temes que tracta són els definits als tractats i, sobre el paper, es basa en la tècnica del contrafactum d'un text cortès preexistent. La majoria dels sirventesos catalans se serveixen d'estructures mètriques molt corrents, i de cap no es pot afirmar que segueixi la regla bàsica d'imitació de la rima d'una peça preexistent. Aquest fet demostra que, potser, el seguiment dels tractats no era estricte i que la pràctica era més aviat deixatada o bé, directament, aliena a segons quines regles. ${ }^{6}$

Així doncs, el sirventès català no és un gènere que hagi de ser entès des d'una perspectiva rígida. Més aviat, l'hem de llegir tenint present la idea última de discurs profâ sobre el món, amb un fort component vituperatiu, sota el prisma d'una doble funció pragmàtica i epideíctica. Des d'una perspectiva històrica, els autors no demostren una ruptura clara amb el sirventès trobadoresc, especialment durant el segle XIV, tot i que és palès un fort procés d'hibridació amb altres gèneres. Perviuen, amb força, el sirventès polític i el moral, que lamenta la decadència dels usos socials però que també incorpora referències de l'àmbit del regiment de prínceps, mentre que cal llegir els poemes satírics ad hominem com a maldits, tal com fan els tractats. Quant a la imitació formal, tan característica del sirventès trobadoresc, cap dels vint-i-vuit sirventesos catalans pren la rima exacta d’un poema conegut, català o occità; només, en alguns casos, el patró mètric.

\section{${ }_{2}$ Catàleg}

\section{I Presentació i abreviatures}

\section{I.I Presentació}

Per a la configuració d'aquest catàleg he considerat el corpus conegut de poesia catalana dels segles XIV-XV. M'he ajudat del $R A O$ de Jordi Parramon (I992) ${ }^{7}$ i del $R I A L C$, així com de les fonts bibliogràfiques que he tingut al meu abast. Seguint els postulats recents sobre una única àrea d'influència occitanocatalana per a la primera meitat del segle XIv (Cabré-Martí-Navàs 2OO9), caldria valorar també l'aportació occitana d'aquest període, de la qual incloc, amb caràcter excepcional, el sirventès de Joan de Castellnou, per les estretes relacions que manté el text amb

6. Per trobar el recte compliment de la norma hem d'anar a textos que no són sirventesos pròpiament dits: és el cas del poema de Pere III sobre les armes del cavaller, "Vetlan el lit, suy 'n un penser casut", l'anònim "Rey qui vilan pren en honor” i el també anònim “Arbre'cçellent, en bon signa plantat”, molt proper a una complexa estructura que només es troba en tres poemes d'Antoni Vallmanya (Parramon i992: 84), tot i que en desconeixem la melodia, si és que en tenien, i les circumstàncies exactes de composició de tots tres.

7. D'acord amb la nomenclatura de Parramon, a partir d'ara em referiré a aquesta obra amb l'acrònim RAO ('Repertori d'Autors i Obres'). 
la noblesa catalana, sens dubte el públic destinatari de la peça. No he tingut en compte els altres poemes occitans d'aquesta època, que el lector pot trobar a faltar-només a la secció moderna del Cançoner Gil o Sg (Barcelona, Biblioteca de Catalunya, ms. I46) hi ha tres sirventesos rubricats de Ramon de Cornet i un de Guillem de Borzac. Tot i tenir voluntat exhaustiva, doncs, el llistat de textos resta forçosament obert, a l'espera de noves recerques que puguin acréixer-lo.

Presento, en primer lloc, el catàleg de sirventesos i, després, amb caràcter independent, els textos que es troben a l'òrbita del gènere, classificats per temes. Ordeno els poemes segons la catalogació de Parramon al $R A O$, ampliada en cas que sigui necessari per la del RIALC. Dono l'íncipit tal com apareix en l'edició moderna de referència. El camp "Rúbrica" el reservo per a precisions de gènere, com ara "sirventesch" o "cobles". En cas que la rúbrica no en reporti, el camp resta buit. En cas que hi hagi més d'una rúbrica que reporti precisions de gènere, faig constar abreujadament el manuscrit. Reprodueixo la rúbrica sencera, tal com la dóna l'editor, al camp "Manuscrits", juntament amb la foliació exacta de cada poema. En cas que l'edició no faci constar la rúbrica, la transcric directament dels manuscrits i en regularitzo i/j, u/v, les majúscules i minúscules, i aglutino els mots segons els usos actuals. Dono la datació dels textos amb la màxima precisió que m’és possible. Essent el sirventès un gènere que, en ocasions, neix motivat per una circumstància històrica, incloc aquest camp amb caràcter breu a la fitxa de catalogació. Finalment, el lector hi trobarà una edició de referència, especificant les pàgines, i l'enllaç del text al RIALC.

2.I.2 Abreviatures de les biblioteques

ASCA L'Alguer. Archivio Storico del Comune di Alghero, Municipi de l'Alguer

ACA Barcelona. Arxiu de la Corona d'Aragó

$\mathrm{BAB} \quad$ Barcelona. Biblioteca de l'Ateneu Barcelonès

BC Barcelona. Biblioteca de Catalunya

DKB Copenhage. Det Kongelige Bibliotek

BAM Montserrat. Biblioteca de l'Abadia de Montserrat

$\mathrm{BnF} \quad$ París. Bibliothèque nationale de France

BUZ Saragossa. Biblioteca General Universitaria de Zaragoza

BUS Salamanca. Biblioteca Universitaria de Salamanca

AHAT Tarragona. Arxiu Històric Arxidiocesà de Tarragona

BHUV València. Biblioteca Històrica de la Universitat de València 
2.2 Catàleg de sirventesos

2.2.I Sirventesos conservats

$\operatorname{mon}$

RAO: 0.66

Autor: Anònim

Íncipit: [...] la croada

Rúbrica: -

Data: I380-I400

Circumstància: Croada dels regnes cristians sobre Barbaria.

Manuscrits:

AHAT, ms. 6o, ff. 3-5 [sense rúbrica]

Edició de referència: Pié 1898: 737-4I

Text: http://www.rialc.unina.it/o.66.htm

$\min 2 \pi$

RAO: og.I

Autor: Anònim

Íncipit: Pus que tothom se n'aparta

Rúbrica: -

Data: $1462^{3 / 3}-63^{1 / 3}$

Circumstància: Enfrontaments entre Joan II i la Generalitat, després que la Generalitat reconegués com a rei Enric IV de Castella.

\section{Manuscrits:}

DKB, ms. $\mathrm{S}_{432}$, ff. $3^{\mathrm{v}-5^{\mathrm{v}}}$ [sense rúbrica]

Edició de referència: Nicolau d'Olwer 1934: 325-28

Text: http://www.rialc.unina.it/og.I.htm 
$\operatorname{mor}$

RAO: og.2

Autor: Anònim

Íncipit: Torbat, perdut en una vall pregona

\section{Rúbrica: -}

Data: $1466^{2 / 3}-7 \mathrm{O}^{3 / 3}$

Circumstància: Posició política de la ciutat de Barcelona envers Joan II, amb referències al conflicte de la Biga i la Busca.

\section{Manuscrits:}

DKB, ms. S432, ff. $3^{\mathrm{v}-5}$; ; Contra Barcelona, fetes en Nàpols

Edició de referència: Nicolau d'Olwer 1934: 328-30

Text: http://www.rialc.unina.it/og.2.htm<smiles>[AlH2][AlH][VH2]</smiles>

RAO: 34.8

Autor: Joan de Castellnou

Íncipit: Tant es lo mons ples d'amor descorteza

Rúbrica: Sirventes

Data: 1339

Circumstància: -

Manuscrits:

BC, ms. I46, Cançoner Gil, ff. IO3r-IO4v; Sirventes d'en Johan de Castellnou

Edició de referència: Massó i Torrents 19I4: 452-55

Text: http://www.rialc.unina.it/34.8.htm 
$5 \pi$

RAO: 47.1

Autor: Pere Despuig

Íncipit: Pus que bondat neç abtesa

Rúbrica: sirventesch [BAB, I; BC, IO; BnF, esp. 225]

Data: $\mathrm{XV}^{2 / 3}$

Circumstància: -

\section{Manuscrits:}

BAB, ms. I, ff. I69r-I69v; sirventesch

BC, ms. 9, ff. I3r-I4r; Mossèn .P. Dezpuig cavaller

BC, ms. IO, ff. I45 ${ }^{\mathrm{V}-\mathrm{I}} 46 \mathrm{v}$; Sirventesch fet per mossèn $\mathrm{p}$ Despuig cavaller

BnF, ms. esp. 225, ff. I3Ov-I3Ir; Mossèn p Dezpuig cavaller sirventesch

Edició de referència: Cabré $2000 \mathrm{a}$

Text: http://www.rialc.unina.it/47.I.htm

$\operatorname{6m}$

RAO: $5^{2 . I}$

Autor: Arnau d'Erill

Íncipit: O tu, traÿdor, qui tan sovint renegues

Rúbrica: -

Data: I4I2-I8

Circumstància: Atac personal contra Ramon Roger d'Erill, nebot de l'autor, després que aquell violés la filla d'aquest, monja, i la deixés embarassada.

\section{Manuscrits:}

BUZ, ms. 2IO, ff. 227v-232r; Nebot fra Ramon Roger d'Erill comanador de Berbens del orde de Sant Johan de Jherusalem lo qual li deÿa que li avia emprenyada una sua filla monge del monestir d'Elguayre

Edició de referència: Riquer I962: 2I2-I8

Text: http://www.rialc.unina.it/52.I.htm 
$\operatorname{mon}$

RAO: $59 \cdot 7$

Autor: Andreu Febrer

Íncipit: Dolorós critz ab votz brava, terribla

Rúbrica: Sirventesch

Data: 1398

Circumstància: Expedició militar contra el nord d'Àfrica.

\section{Manuscrits:}

BC, mss. 7 i 8, Cançoner Vega-Aguiló, ff. 67r-68r; Sirventesch fet per Andreu Febrer per lo passatge de Barbaria

Edició de referència: Riquer 1951: 87-90

Text: http://www.rialc.unina.it/59.7.htm<smiles>[Li]O[Hg]</smiles>

RAO: $63 . \mathrm{I}$

Autor: Joan Ramon Ferrer

Íncipit: Com sia just, per gran manutanença

Rúbrica: Sirventesch

Data: $\mathrm{XV}^{\mathrm{T} / 3}$

Circumstància: Defensa de l'honor de Joan Valentí, blasmat per haver mort per amor. L'autor rebat aquest fet $\mathrm{i}$ ataca dialècticament els acusadors de Valentí.

\section{Manuscrits:}

BC, mss. 7 i 8, Cançoner Vega-Aguiló, ff. 98r--Ioor; Sirventesch, preceptes retoricals observant per leonismitat simpla d'accent greu, disuasint dir Johan Valentí, lohablement junyint, aver presa mort casual per amors, pus qu'és presupposat aquell ésser de virtuts illustrat; lo qual fou fet per lo magnífich mossèn Johan Ramon Fferrer, cavaller e doctor en cascun dret.

Edició de referència: Cabré 2002: 242-52

Text: http://www.rialc.unina.it/63.I.htm 
$9 \pi$

RAO: 96.3

Autor: Pere March

Íncipit: $\mathrm{Al}$ punt $\mathrm{c} \cdot \mathrm{om}$ naix comensa de morir

Rúbrica: -

Data: $1372-89$

Circumstància: -

\section{Manuscrits:}

BAB, ms. I, ff. I24V-I25v; Mossen p. march

BC, mss. 7 i 8, Cançoner Vega-Aguiló, ff. 26r-27v; Mossen P. march

BC, ms. 9, ff. 2v-4r; Mossen .P. march

BC, ms. IO, ff. I 42 r-I 43 r; Mossen P. march

BnF, ms. esp. 225, ff. I26r-I27r; Mossen .P. march

BUS, ms. 2.244, ff. I55 ${ }^{\mathrm{V}-\mathrm{I}} 57 \mathrm{r}$; Mossen pe march

BUZ, ms. 2IO, ff. IO4r-IO5r [...] .p. march

Edició de referència: Cabré I993: I3I-39

Text: http://www.rialc.unina.it/g6.3.htm

$\operatorname{miO} \pi$

RAO: 96.5

Autor: Pere March

Íncipit: Cest falç de món no·l presi un pugés

Rúbrica: -

Data: $1372-89$

Circumstància: -

Manuscrits:

BC, mss. 7 i 8, Cançoner Vega-Aguiló, ff. 29v-3rr; Mossen .P. march BUZ, ms. 2IO, ff. IO5V-IO ${ }^{\mathrm{r}}$; Mossen .p. march

Edició de referència: Cabré 1993: I48-54

Text: http://www.rialc.unina.it/g6.5.htm 
II $\%$

RAO: 96.6

Autor: Pere March

Íncipit: Cest qui ço fay d'on li deu seguir dan

Rúbrica: -

Data: $1372-89$

Circumstància: -

Manuscrits:

BAB, ms. I, ff. І26r-I26v; Mossen .P. march

BC, ms. 9, ff. $4 \mathrm{v}^{\mathrm{V}}-5 \mathrm{v}$; Mossen .P. march

BC, ms. IO, ff. I $43^{\mathrm{r}-\mathrm{I}} 43^{\mathrm{V}}$; Mossen .P. march

BnF, ms. esp. 225, ff. I27v-I28r; Mossen P. march

Edició de referència: Cabré 1993: I6I-65

Text: http://www.rialc.unina.it/g6.6.htm

$12 \pi$

RAO: 96.9

Autor: Pere March

Íncipit: Jo·m meravelh com no·s ve qui hulhs ha

Rúbrica: -

Data: $1372-89$

Circumstància: -

Manuscrits:

BAB, ms. I, ff. I23r-I24r; Mossen P march

BC, mss. 7-8, Cançoner Vega-Aguiló, 28r-29r; Mossen .P. march

BC, ms. 9, ff. Ir-2v; Mossen .P. march

BC, ms. IO, ff. I4Ir-I $42 \mathrm{v}$; Mossen .P. march

BnF, ms. esp. 225, ff. I25r-I26r; Mossen pera march

BUZ, ms. 2IO, ff. IO2V-IO3V [sense rúbrica]

Edició de referència: Cabré 1993: I40-47

Text: http://www.rialc.unina.it/g6.g.htm 
$m 13 m$

RAO: 96 .II

Autor: Pere March

Íncipit: Tots grans senyors qui bé vol avenir

Rúbrica: Siruentesch [BC, 7-8]

Data: $1372-89$

Circumstància: -

Manuscrits:

BC, mss. 7-8, Cançoner Vega-Aguiló, ff. 32r-33v; Siruentesch de Mossen P. march

BUZ, ms. 2IO, ff. IO7r-IO7v; Mosen .p. march

Edició de referència: Cabré I993: I55-60

Text: http://www.rialc.unina.it/g6.ır.htm

$\lim \pi$

RAO: $99 \cdot 5$

Autor: Pero Martines

Íncipit: Mer[a]vellat stich de ço que hoig

Rúbrica: Cobles

Data: Febrer-març de I46I

Circumstància: Poema anticastellà després que un grup de partidaris de Carles de Viana ataquessin i prenguessin el castell de Fraga, sota la vigilància de Martí de Lanuza i Diego de Guzmán.

\section{Manuscrits:}

BAM, ms. 992, Cançoner del Marquès de Barberà, ff. Ir-Iv; Cobles fetes per don [Diego de Gusman], de la fuyta del castell de Fragua en lo temps del infortuni del illustre don Karles, primogenit d'Arago

Edició de referència: Riquer I944: 222-23

Text: http://www.rialc.unina.it/99.5.htm 
$\operatorname{mon}$

RAO: IOI.4

Autor: Guillem de Masdovelles

Íncipit: En breu veyrem torney mortal bastir

Rúbrica: sirventesch

Data: 1389

Circumstància: Guerra contra la invasió dels armanyaguesos.

\section{Manuscrits:}

BC, ms. II, Cançoner dels Masdovelles, ff. Io8r-Io8v; Lo sirventesch devall scrit feu En Guillem de Masdovelles, en lo temps de la guerra dels armenyaguesos; lo qual dressa a mossen Ramon d'Ebella, en companyia del qual ell era en la dita guerra

Edició de referència: Aramon i Serra 1938: 189-90

Text: http://www.rialc.unina.it/IOI.4.htm

$m \mathbf{I} m$

RAO: IOI.I5

Autor: Guillem de Masdovelles

Íncipit: Senyor mot naut: l'autrier me ffes demanda

Rúbrica: sirventesch

Data: 1394

Circumstància: Setge militar de Catània per part de les tropes catalanes.

\section{Manuscrits:}

BC, ms. II, Cançoner dels Masdovelles, ff. Io8v-Iogr; Lo sirventesch devall scrit ffeu lo dit En Guillem de Masdovelles al citi de Catania, per manament del duch de Monblanch, l'inffant don Marti, qui apres fonch rey d'Araguo

Edició de referència: Aramon i Serra I938: I9I-92

Text: http://www.rialc.unina.it/IOI.I5.htm 
mI 7 or

RAO: 103.23

Autor: Joan Berenguer de Masdovelles

Íncipit: Aquests grans fets perseguits fins havuy

Rúbrica: obre

Data: I46I

Circumstància: Presó de Carles de Viana.

\section{Manuscrits:}

BC, ms. II, Cançoner dels Masdovelles, ff. I38r- I39v; [al peu:] L'obre demunt scrita remeti a Lleyda, per mossen Bnt. Calba, la qual dix dona al reverent archabisbe de Terraguona, a qui s'edressa, ab tot sia per tota Catalunya e la mjsetgeria de .LX. personas qui per la deslliurança de don Carles, prinsep de Viana, eran per anbaxadors al senyor rey

Edició de referència: Aramon i Serra 1938: 233-34

Text: http://www.rialc.unina.it/IO3.23.htm

$m \mathbf{I 8}$

RAO: $103 \cdot 34$

Autor: Joan Berenguer de Masdovelles

Íncipit: Cuytau, senyor, per ffer a Deu servey

Rúbrica: obre

Data: Juliol de I 467

Circumstància: Rebel-lió de la ciutat de Barcelona contra Joan II.

\section{Manuscrits:}

BC, ms. II, Cançoner dels Masdovelles, ff. I45 v-I 47 r; L'obre devall scrita fiu en lo mes de juljol any .M.CCCC.LXVII., com lo duch Johan fonch entrat a Barçalona, presentada a mon bon rey he senyor, que Deu guart

Edició de referència: Aramon i Serra 1938: 243-45

Text: http://www.rialc.unina.it/IO3.34.htm 
$m 19 m$

RAO: 103.67

Autor: Joan Berenguer de Masdovelles

Íncipit: Estant ratret e d'enuig fatiguat

Rúbrica: -

Data: $\mathrm{XV}^{2 / 3}$

Circumstància: Atac contra el clergat.

\section{Manuscrits:}

BC, ms. II, Cançoner dels Masdovelles, ff. 3r-3v; J. M. G.

Edició de referència: Aramon i Serra 1938: 263-65

Text: http://www.rialc.unina.it/IO3.67.htm

m20

RAO: IO3.68

Autor: Joan Berenguer de Masdovelles

Íncipit: Ffeeltat vol amar la senyoria

\section{Rúbrica: -}

Data: Febrer de I 464

Circumstància: Rebel-lió de la ciutat de Barcelona contra Joan II.

\section{Manuscrits:}

BC, ms. II, Cançoner dels Masdovelles, I47r-I47v; Lo dit Masdovell[e]s De feeltat. En fabrer de l'ay.LXIIII.

Edició de referència: Aramon i Serra 1938: 245-46

Text: http://www.rialc.unina.it/Ioz.68.htm 
RAO: I03.I25

Autor: Joan Berenguer de Masdovelles

Íncipit: Prenguen espill los curials que son

\section{Rúbrica: -}

Data: 1453

Circumstància: Mort d'Álvaro de Luna i primers enfrontaments entre Carles de Viana i Joan de Navarra.

\section{Manuscrits:}

BC, ms. Io, ff. IIOv-IIIr; Mossèn Berenguer de Masdovelles

BnF, ms. esp. 225, ff. 222r-222v [sense rúbrica]

Edició de referència: Torres Amat 1836: 408-o9

Text: -

$22 \pi$

RAO: IO3.I38

Autor: Joan Berenguer de Masdovelles

Íncipit: Quanta dolor a passada lo rey

Rúbrica: hobra

Data: Desembre de I46o

Circumstància: Presó de Carles de Viana.

\section{Manuscrits:}

BC, ms. II, Cançoner dels Masdovelles, ff. I36r-I37r; La hobra deuall s[cr]ita fiu, en lo mes de deembre any .M.CCCC.LX., sobre la preso que feu lo senyor rey en Johan d'Areguo de son fill don Carles, prinsep de Viana, en la ciutat de Leyda; la qual li tremati per mossen Luys de Vich, qui aquella li dona

Edició de referència: Aramon i Serra I938: 229-3I

Text: http://www.rialc.unina.it/IO3.I38.htm 
RAO: IO3.I42

Autor: Joan Berenguer de Masdovelles

Íncipit: Regne divis es desolat, perdut

Rúbrica: Obra [BAB, I]; hobre [BC, II]

Data: Gener de I 459

Circumstància: Entrada de Joan II a Catalunya, en els anys previs a la guerra civil catalana.

\section{Manuscrits:}

BAB, ms. I, ff. I86v-I87v; Mossèn Johan Baranguer de Masdovelles obra presentada al .S.R. a Vilafrancha de Penadès en l'any .M.CCCC.LVIIII

BC, ms. II, Cançoner dels Masdovelles, ff. I34-r-I4Or; La hobre devall sc[ri]ta fiu jo, Johan Berenguer de Masdovelles, per la nova entrada en lo regne del senyor rey don Johan, la qual li presenti en la vila de Vilafrancha a .XVII. de janer any .M.CCCC.LVIIII ${ }^{\circ}$., en la casa de Johan Terre, hun lo dit senyor posava, presents lo reverent mestre de Muntesa he de Sent Jordi, lo fill del dit senyor, que era mestre de Calatrava, don Pedro d'Urreya, don Caros, mossen Rebolledo, he don Llop de Gurreya, ffill de mossen Marti Torrellas, he molts d'altres homens d'onor; lo qual, apres agui llegida he presentada al dir senyor, lo dit mestre de Montesa pres he torna llegir

Edició de referència: Aramon i Serra 1938: 227-29

Text: http://www.rialc.unina.it/IO3.I42.htm

$\min 24 \pi$

RAO: IO3.I47

Autor: Joan Berenguer de Masdovelles

Íncipit: Si la fe fos per los tots be tenguda

Rúbrica: hobre

Data: Agost de I 464

Circumstància: Rebel.lió catalana contra Joan II.

\section{Manuscrits:}

BC, ms. II, Cançoner dels Masdovelles, ff. I43v-I44r; La hobre devall scrita, a .XXII. d'eguost any .M.CCCC.LXIIII., assi en la ciutat de Terraguona, a mon rey he senyor, per la gracia de 
Deu, don Johan, presenti jo, Johan Berenguer de Masdovell[e]s, presens ma senyora he reyna, l'archabisbe de Caraguosa, don Alfonso d'Eraguo, fills del dit mon rey he senyor, don Anrich infant nabot, don Lop d'Urreya he don Pedro frares, mossen Rodriguo de Rebolledo, don Loch de Gurreya, don Mateu de Muncada e molts altres varons, cavallers he gentils homens; he a la dita ma reyna he senyora, l'obra apres seguent d'equesta [als marges:] Nota que fonch vençut en lo fabrer de l'any .LXV. Mori lo dit Pedro a .XXVIII. de juny any .LXVI. a Grenolers e portat a Barçalona [al peu:] En la derreria del mes de febrer o en l'antrada de març en l'any .M.CCCC.LXVI., lo senyor primogenit don Ferrando d'Ereguo he capita lo compte de Prades, a Calaf fon vençut En Pedro de P[or]togual, e ... los bescomptes de Roda ... e de ... Servelo, En ... de Peratalada e

Edició de referència: Aramon i Serra 1938: 237-38

Text: http://www.rialc.unina.it/IO3.I47.htm

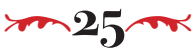

RAO: IO3.I5I

Autor: Joan Berenguer de Masdovelles

Íncipit: Siau menbrant de so us deu recordar

Rúbrica: hobre

Data: $146 \mathrm{O}^{3 / 3}-\mathrm{I} 46 \mathrm{I}^{\mathrm{I} / 3}$

Circumstància: Presó de Carles de Viana.

\section{Manuscrits:}

BC, ms. II, Cançoner dels Masdovelles, ff. I37r-138r; La hobre devall scrita tremeti, per lo dit mossen Luys de Vich al don Carles, prinsep de Viana, fill del dit senyo[r] rey d'Araguo, sobre la sua preso la qual li fonch donada

Edició de referència: Aramon i Serra I938: 23I-32

Text: http://www.rialc.unina.it/IO3.I5I.htm 


\section{6}

RAO: I45.I

Autor: Lluís de Requesens

Íncipit: Ans de molt temps veureu los confessós

Rúbrica: Cobbles [BAB, I]

Data: c. I432

Circumstància: Atac contra el clergat, per un conflicte de jurisdiccions entre Lluís de Requesens, senyor de Monnars i representant dels interessos reials, i l'arquebisbat de Tarragona.

\section{Manuscrits:}

BAB, ms. I, ff. I74v-I75v; Cobbles ffetes per mossen Luys de Requesens

BnF, ms. esp. 225, ff. 2I2r-2I3v [text il.legible]; [al peu:] Mossen luis de requesens

Edició de referència: Torró 2009: 63-7I

Text: http://www.rialc.unina.it/I45.I.htm

$27 m$

RAO: $167 . \mathrm{I}$

Autor: Ramon Savall

Íncipit: De mal saber, ab verinos coratge

Rúbrica: -

Data: c. 1396

Circumstància: Denúncia de la corrupció moral de la societat, probablement com a conseqüència dels esdeveniments que envoltaren la mort del rei Joan I.

\section{Manuscrits:}

BUZ, ms. 2IO, ff. 226r-227r; Ramon Cavall

Edició de referència: Cabré 200ob

Text: http://www.rialc.unina.it/I67.I.htm 


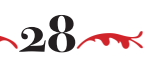

RAO: I8I.2

Autor: Pere Tresfort

Íncipit: Gran carrech han huy tuyt l'om de paratge

Rúbrica: -

Data: $\mathrm{XIV}^{3 / 3}-\mathrm{XV}^{\mathrm{T} / 3}$

Circumstància: Denúncia de la decadència moral de la noblesa, probablement, amb motiu de les bandositats que patí la corona d'Aragó a finals del segle XIV i principis del XV.

\section{Manuscrits:}

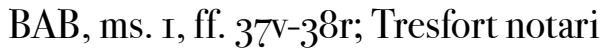

BC, ms. 9, ff. I8v-I9v; Tresfort notari

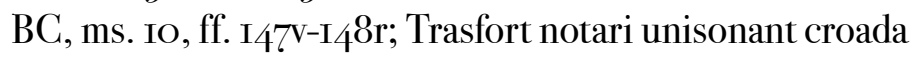

BnF, ms. esp. 225, ff. I32V-I33r; Trasfort notari unisonant croada

Edició de referència: Cabré $2000 \mathrm{c}$

Text: http://www.rialc.unina.it/I8I.2.htm

\subsubsection{Sirventesos no conservats}

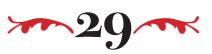

RAO: -

Autor: Pere March

Íncipit: -

Rúbrica: -

Data: [1374]

Circumstància: Cicle de sirventesos de 1374 .

Fonts documentals:

ACA, reg. I740, ff. 63 r-64r i $65^{\mathrm{r}}$

Edició de referència: Rubió i Lluch I9O8-2I: I, 252-54

Text: - 
30 m

RAO: -

Autor: Infant Pere d'Aragó

Íncipit: -

Rúbrica: -

Data: [1328]

Circumstància: Festes de coronació d'Alfons el Benigne.

Fonts documentals:

Crònica de Ramon Muntaner, capítol 298

Edició de referència: Coll i Alentorn I927-54: 9, 26-27

Text: -

$\operatorname{mi}$ 尓

RAO: -

Autor: Pere III de Catalunya-Aragó, el Cerimoniós

Íncipit: -

Rúbrica: -

Data: 1354

Circumstància: Expedició militar a Sardenya, assetjada per la pesta.

\section{Fonts documentals:}

ACA, reg. IO25, f. IO4r

ACA, reg. 980, ff. 8Ir i 93r-93v

Edició de referència: Rubió i Lluch I9O8-2I: I, I68; 2, IO5

Text: - 


\subsection{Catàleg de textos a l'òrbita del sirventès}

2.3.I Poemes sobre la caiguda de Constantinoble

\subsection{I.I Poemes atribuïbles directament al certamen d'Antoni Saplana}

$\propto \mathbf{I} \Longleftarrow$

RAO: 99.IO

Autor: Pero Martines

Íncipit: Singular preu, salut d'umana pensa

Rúbrica: Lahors de la Creu

Data: c. $1453-55$

Circumstància: Lloança de la Creu i exaltació a la croada per la caiguda de Constantinoble.

\section{Manuscrits:}

BC, ms. IO3O, ff. IO3r-IO4v; Lahors de la Creu, ffetes per una joya que ffonch mesa en Barcelona sobre la creuada contra.l turch, animant la gent

Edició de referència: Riquer 1997: 57-59

Text: http://www.rialc.unina.it/99.Io.htm

$\simeq 2 \Longleftarrow$

RAO: I4O.I; I4O.3

Autor: Francí Joan Puculull

Íncipit: ¿Qual hom sentit porà dir ni penssar?; Arbre molt sant en qual bé ha granat

Rúbrica: Hobra; vers

Data: c. $1453-55$

Circumstància: Lloança de la Creu i exaltació a la croada per la caiguda de Constantinoble.

\section{Manuscrits:}

BnF, ms. 226, ff. I7r-ıgv; Hobra feta per Ffransí Johan Puculull en lo consistori de mossèn Anthony Caplana, lo qual posà una joya a qui millor diguera en laor de la Creu animant los cristians que anassen a la crohada justada; [a l'inici de la tercera cobla]: Lo vers tirant a la joya

Edició de referència: Riquer I997: 53-56 
Text: http://www.rialc.unina.it/I40.I.htm $; \underline{\text { http://www.rialc.unina.it/I40.3.htm }}$

2.3.I.2. Poemes no atribuïbles directament al certamen d'Antoni Saplana

$\because 3 \smile$

RAO: O.I5

Autor: Anònim

Íncipit: Arbr'ecçellent, en bon signa plantat

\section{Rúbrica: -}

Data: c. $1453-55$

Circumstància: Lloança de la Creu i exaltació a la croada per la caiguda de Constantinoble.

\section{Manuscrits:}

BUZ, ms. 2IO, ff. 305-307v [sense rúbrica]

Edició de referència: Cabré $2000 d$

Text: http://www.rialc.unina.it/O.I5.htm

$\because 4 \Longleftarrow$

RAO: o.I6

Autor: Anònim

Íncipit: Armem-nos, vers cristians

Rúbrica: -

Data: c. $1453-55$

Circumstància: Lloança de la Creu i exaltació a la croada per la caiguda de Constantinoble.

\section{Manuscrits:}

BAB, ms. I, f. 2IIr [sense rúbrica]

Edició de referència: Riquer 1997: 8I-82

Text: http://www.rialc.unina.it/O.I6.htm 


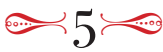

RAO: 67.3

Autor: Joan Fogasot

Íncipit: Dels doctes fels congregat per posible

Rúbrica: laors de la Creu

Data: c. I $453-55$

Circumstància: Lloança de la Creu i exaltació a la croada per la caiguda de Constantinoble.

\section{Manuscrits:}

BAB, ms. I, ff. 2Ov-22r; Obra feta per en Johan Fogasot, notari, en laors de la Creu e animant los christians de anar contra lo gran turch per la presa de Constantinoble [al marge:] Acò dich per quant en lo mes de juliol del any MCCCCliiij, trobant-me jo, Johan Foguasot, notari en Nèpols, en companyia del honorable mossèn Thomàs Pujades, Cònsol de la mar de Berchelona e misatjer tramès per l'astament mercantívol de la dita ciutat al S[enyor] $\mathrm{R}$ [ei] Alfonso, viu los enbaxadors de Constentinoble vestits de dol ab molta dolor e congoxa dir la nova de la dita presa a la presan[t]a M[agestat], a la qual eren venguts per demanar cocós contra lo gran Turch

Edició de referència: Riquer I997: $65^{-67}$

Text: http://www.rialc.unina.it/67.3.htm

$\approx 6 \Longleftarrow$

RAO: IO3.II9

Autor: Joan Berenguer de Masdovelles

Íncipit: Permès a Déu haver feta presó

Rúbrica: Obra [...] e laors de la Creu

Data: c. $1453^{-55}$

Circumstància: Lloança de la Creu i exaltació a la croada per la caiguda de Constantinoble.

\section{Manuscrits:}

BAB, ms. I, ff. I8r-2ov; Obra feta per lo dit mossèn Johan Baranguer de Masdovell[e]s, cavaller, sobre la presó de Constantinoble e laors de la Creu

Edició de referència: Riquer 1997: 6o-64

Text: - 
2.3.2 Poemes i possibles fragments de matèria moral o política

I

RAO: O.I2I

Autor: Anònim

Íncipit: Rey qui vilan pug'en honor

Rúbrica: Esparça

Data: Anterior a 1420

Circumstància: -

\section{Manuscrits:}

BC, mss. 7 i 8, Cançoner Vega-Aguiló, f. 2ov; Esparça

Edició de referència: Alberni 2003: 465

Text: http://www.rialc.unina.it/O.I2I.htm

$2\}$

RAO: obis

Autor: Anònim

Íncipit: O visconte de Narbona

Rúbrica: Cobles

Data: posterior al cinc de maig de I4I2

Circumstància: Assalt de la ciutat de l'Alguer per part del vescomte de Narbona la nit del cinc al sis de maig de I4I2.

\section{Manuscrits:}

ASCA, ms. 503, ff. 8Ir-83r; Cobles de la conquista dels francesos [Co a l'inici de cada cobla]

Edició de referència: Bover i Font 1993: I7-2I

Text: http://www.rialc.unina.it/obis.o visconte.htm 
33

RAO: obis

Autor: Anònim

Íncipit: Pus que-s perdet en mercaders la fes

Rúbrica: -

Data: segle XIV

Circumstància: -

Manuscrits:

BC, ms. 309, f. 79r [sense rúbrica]

Edició de referència: Grapí 20OI

Text: http://www.rialc.unina.it/obis.pus que.s perdet.htm

24

RAO: I7.I

Autor: Bertomeu

Íncipit: En lo mon trop molts homens ralladors

Rúbrica: -

Data: segle $\mathrm{XV}^{2 / 3}$

Circumstància: Atac contra els homes xerraires.

\section{Manuscrits:}

BAB, ms. I, f. I68r; Altra

BC, ms. Io, f. I28v; Altre de Berthomeu de mossèn Corella

BnF, ms. esp. 225, f. ro2v; Altre de Berthomeu de mossèn Corella [ratllat:] Altra a [...] elles

Edició de referència: Cabré 2oooe

Text: http://www.rialc.unina.it/I7.I.htm 
2.5

RAO: 30.3

Autor: Pere Miquel Carbonell

Íncipit: Homens inichs e plens de males fades

Rúbrica: Cobles ab tornada

Data: $5_{5} \mathrm{IO}$

Circumstància: Atac contra aquells que es burlen de la figura de l'arxiver, que en aquest cas coincideix amb el mateix Carbonell.

\section{Manuscrits:}

BC, Memorial 49, f. I26v; Cobles ab tornada contra aquells qui inicament e ab enveia han instat e procurat contra lo archiver fer dita constitucio en lany mil $\mathrm{dx}$

Edició de referència: Bofarull I864-65: I, 323; versions d'autor alternatives a 3 I9 i 32 I

Text: http://www.rialc.unina.it/30.3.htm

? 6

RAO: 30.7

Autor: Pere Miquel Carbonell

Íncipit: Son escrivans ab poca consciença

Rúbrica: Coble

Data: $\mathrm{XV}^{3 / 3}-\mathrm{XVI}^{\mathrm{I} / 3}$

Circumstància: Atac contra els mals escrivans.

\section{Manuscrits:}

ACA, Registre de Conclusions Civils de la Reial Audiència del Principat de Catalunya (I480I484), f. 295v; Coble composta per pere miquel carbonell archiver del rey nostre senyor contra los negligents scrivans lexants spays blancs no continuant hi les conclusions

Edició de referència: Bofarull I864-65: I, 3을

Text: http://www.rialc.unina.it/30.7.htm 
$2,8\}$

RAO: 7O.I

Autor: Pere Galvany

Íncipit: Pus vey lo mon es vengut en tal cas

Rúbrica: -

Data: $137^{8}-\mathrm{I} 4 \mathrm{I} 7$

Circumstància: Cisma d'Occident.

Manuscrits:

BUZ, ms. 2IO, f. 226r; Pere Galvany per lo sisme [...]

Edició de referència: Cabré 2000 f

Text: http://www.rialc.unina.it/7O.I.htm

28

RAO: 132.2

Autor: Pere III de Catalunya-Aragó

Íncipit: Mon char fill, per Sanct Antoni

Rúbrica: Cobles

Data: Novembre de I379

Circumstància: Matrimoni de l'infant Joan amb Violant de Bar.

Manuscrits:

ACA, ms. 26, f. 2oor; Cobles

Edició de referència: Cluzel I957-58: 364-66

Text: http://www.rialc.unina.it/I32.2.htm 
29

RAO: 132.3

Autor: Pere III de Catalunya-Aragó

Íncipit: Vetlan el lit, suy’n un penser casut

Rúbrica: Cobles

Data: Agost de I378

Circumstància: Consells sobre la manera d'armar cavallers dirigits a l'infant Martí.

\section{Manuscrits:}

ACA, ms. 26, f. 202r; Cobles fetes per lo senyor rei

Edició de referència: Cluzel 1957-58: 366-67

Text: http://www.rialc.unina.it/I32.3.htm

IOS

RAO: I88.I

Autor: Huguet del Vellat

Íncipit: En breu veyrem una freyor abatre

\section{Rúbrica: -}

Data: segle $\mathrm{XIV}^{2 / 2}$

Circumstància: Profecia apocalíptica.

\section{Manuscrits:}

BC, mss. 7 i 8, Cançoner Vega-Aguiló, ff. 92r-92v; D’Uguet del Velhat

Edició de referència: Cabré $2000 g$

Text: http://www.rialc.unina.it/I88.I.htm 


\section{$2.3 \cdot 3$ Poemes de sàtira personal i maldits contra homes}

(I)

RAO: 0.75

Autor: Anònim

Íncipit: Lo menyscap de la moneda

Rúbrica: Cobles

Data: $1454-55$

Circumstància: Atac personal seguint el model de les cobles de "la panadera" contra un jurista anomenat Mallol, vilipendiat i ridiculitzat per la seva inexpertesa.

\section{Manuscrits:}

BC, ms. 2, ff. Io3v-IO4V; Cobles de la panadera

Edició de referència: Riquer I986: 445-50

Text: http://www.rialc.unina.it/0.75.htm

\section{(2)}

RAO: 0.87

Autor: Anònim

Íncipit: Mossen Johan, pus sou desnaturat

Rúbrica: Latovari

Data: segle XV?

Circumstància: Atac personal en forma de paròdia grollera d'un lletovari.

\section{Manuscrits:}

BAB, ms. I, ff. 79r-79v; Latovari

Edició de referència: Aramon i Serra [1953]: 144

Text: http://www.rialc.unina.it/o.87.htm 
$(3)$

RAO: 0.92

Autor: Anònim

Íncipit: No·m sé si s’és mon servell

Rúbrica: Maldit [BAB, I]; Obre [BUZ, 2IO]

Data: $1453^{-65}$

Circumstància: Atac personal seguint el model de les cobles de "la panadera” contra Joan Fajadell.

\section{Manuscrits:}

BAB, ms. I, ff. $84 \mathrm{v}-85^{\mathrm{r}}$; Maldit

BUZ, ms. 2IO, f. Io8v; Obre ffeta per lo capella fagadell benefficiat en la çeu de barcelona

Edició de referència: Rodríguez Risquete 2002: 388-9I

Text: http://www.rialc.unina.it/o.92.htm

$(4)$

RAO: 0.93

Autor: Anònim

Íncipit: No us vullau metre·n amar

Rúbrica: Maldit

Data: segle $\mathrm{XV}^{2 / 3}$

Circumstància: Atac personal seguint el model de les cobles de "la panadera".

Manuscrits:

BAB, ms. I, ff. 82v-84r; Maldit

Edició de referència: Archer I996: II6-2I

Text: http://www.rialc.unina.it/o.93.htm 
$(5)$

RAO: ob.I

Autor: Anònim

Íncipit: Nuyl temps no nasch corona

Rúbrica: -

Data: Anterior a 1348

Circumstància: Atac personal contra el Capellà de Bolquera.

Manuscrits:

Terç del Chrestià, cap. 95o [sense rúbrica]

Edició de referència: Badia I983: 299-300

Text: http://www.rialc.unina.it/ob.I.htm

(6)

RAO: 19.I

Autor: Andreu de Boixadors

Íncipit: Pus mon cosi me trau de pressa tanta

\section{Rúbrica: -}

Data: segle Xv?

Circumstància: Atac personal contra el cosí de l'autor.

\section{Manuscrits:}

BUZ, ms. 2IO, f. 273r; Andreu de Boxadors

Edició de referència: Cabré 2oooh

Text: http://www.rialc.unina.it/Ig.I.htm 
(7)

RAO: 6ra.I

Autor: Francesc Ferrer

Íncipit: Aveu lexat ut re mi fa sol lla

Rúbrica: -

Data: $1453-68$

Circumstància: Atac personal pertanyent al cicle contra Bernat del Bosc.

\section{Manuscrits:}

BUZ, ms. 2IO, f. IOzv; Ffrancesch farrera

[Anotació al marge inferior, molt deteriorada:] malvat [...] Qui pora de ses erros [...] castigar

Edició de referència: Rodríguez Risquete 2002: 383-84

Text: http://www.rialc.unina.it/6ra.I.htm

(8)

RAO: 86.I

Autor: Perot Joan

Íncipit: Dicatis qui us ha ginyat

Rúbrica: -

Data: $1453-68$

Circumstància: Atac personal pertanyent al cicle contra Bernat del Bosc.

Manuscrits:

BUZ, ms. 2IO, ff. Io6v-IO7r; Perot Johan

Edició de referència: Rodríguez Risquete 2002: 384-85

Text: http://www.rialc.unina.it/86.I.htm 
(9)

RAO: IOI.I4

Autor: Guillem de Masdovelles

Íncipit: Reunabblament, per gran desconaxença

Rúbrica: Comjat

Data: $1405^{-38}$

Circumstància: Adoptant el gènere del comiat, reservat normalment per a la temàtica amorosa, el poeta anuncia que s'allunya del seu senyor, Guerau de Cervelló.

Manuscrits:

BC, ms. II, Cançoner dels Masdovelles, ff. 63v-64r; Comjat ffet per En Guillem de Masdovelles

Edició de referència: Aramon i Serra 1938: 122-23

Text: http://www.rialc.unina.it/IOI.I4.htm

(IO)

RAO: I29.I

Autor: Simó Pastor

Íncipit: Per divulgar la practica dampnada

Rúbrica: maldit [BAB, I]; Maldit [BC, IO]

Data: segle $\mathrm{XV}^{2 / 2}$

Circumstància: Atac personal i denigrant contra un home sense referències explícites.

Manuscrits:

BAB, ms. I, ff. I53r-I54r; Altra obra, ço és maldit, fet per en Simon Pastor BC, ms. IO, ff. I83r-I83v; Maldit fet per simon pastor

Edició de referència: Archer I996: IO8-I2

Text: http://www.rialc.unina.it/I2g.I.htm 


\section{(II)}

RAO: 154.16

Autor: Joan Roís de Corella

Íncipit: In utroque iure gran doctor, com somies

Rúbrica: maldit [BAB, I]; Maldit [BC, IO]

Data: $1453-65$

Circumstància: Atac personal pertanyent al cicle contra Bernat del Bosc.

\section{Manuscrits:}

BUZ, ms. 210, ff. Io6v-IO8v [sense rúbrica]

BHUV, ms. R-2804, ff. I39r-I39v; Dell mateix a bernat del bosch

Edició de referència: Rodríguez Risquete 2002: 382-83

Text: http://www.rialc.unina.it/I54.I6.htm

\section{Agraïments}

Aquest article és resultat del treball final del Màster Oficial Interuniversitari d'Estudis Avançats en Llengua i Literatura Catalanes (MOEILLC), UAB-UB. Agraeixo a Josep Pujol el mestratge i les incomptables observacions enriquidores; a totes aquelles persones que em van ajudar, la seva predisposició desinteressada, i al tribunal que el va jutjar, les remarques valuoses que en va fer. Aquestes pàgines no haurien estat, d'altra manera, possibles. 


\title{
4 Obres citades
}

\author{
4.I Fonts d'aquest catàleg
}

Alberni, Anna. 2003. 'El Cançoner Vega-Aguiló (BC, mss. 7 i 8): estructura i contingut' (unpublished doctoral thesis, Universitat de Barcelona) $<$ https://www.tdx.cat/ handle/Io803/I679> [accessed I8-O7-2018]

Aramon i Serra, Ramon (ed.). I938. Cançoner dels Masdovelles, Cançoners Catalans de la Biblioteca de Catalunya, I (Barcelona: Institut d'Estudis Catalans; Biblioteca de Catalunya)

Aramon i Serra, Ramon (ed.). [1953]. Cançoner de l'Ateneu (Barcelona: Institut d'Estudis Catalans, proves d'impremta)

Archer, Robert. 1996. 'Tres “maldits” inéditos contra hombres', Revista de Filología Románica, I3: IO7-I2I

Badia, Lola. 1983. Poesia catalana del segle XIV: edició i estudi del 'Cançoneret de Ripoll'(Barcelona: Quaderns Crema)

Bofarull, Manuel de (ed.). I864-65. Opúsculos inéditos del cronista catalán Pedro Miguel Carbonell (Barcelona: Imprenta del Archivo)

Bover i Font, August. I993. 'Relació i Cobles de la conquista dels francesos: textos anònims algueresos del segle Xv', Catalan Review, 7: 9-36

Cabré, Lluís (ed.). r993. Pere March Obra completa, Els Nostres Clàssics A, I32 (Barcelona: Barcino)

Cabré, Miriam (ed.). 200oa. Pere Despuig 'Pus que bondat neç abtesa', in RIALC: Repertorio informatizzato dell'antica letteratura catalana (Napoli: Università di Napoli Federico II) < http:// www.rialc.unina.it/47.I.htm> [accessed I8-O7-2018]

Cabré, Miriam (ed.). 2ooob. Ramon Savall ‘De mal saber, ab verinos coratge', in RIALC: Repertorio informatizzato dell'antica letteratura catalana (Napoli: Università di Napoli Federico II) <http:// www.rialc.unina.it/I67.I.htm > [accessed I8-O7-20I8]

Cabré, Miriam (ed.). 20ooc. Pere Tresfort 'Gran carrech han huy tuyt l'om de paratge', in RIALC: Repertorio informatizzato dell'antica letteratura catalana (Napoli: Università di Napoli Federico II) <http://www.rialc.unina.it/I8I.2.htm $>$ [accessed I8-O7-2OI8]

Cabré, Miriam (ed.). 2oood. Anònim 'Arbr'ecçellent, en bon signa plantat', in RIALC: Repertorio informatizzato dell'antica letteratura catalana (Napoli: Università di Napoli Federico II) <http:// www.rialc.unina.it/O.I5.htm $>$ [accessed I8-O7-2018]

Cabré, Miriam (ed.). 2oooe. Bertomeu 'En lo mon trop molts homens relladors', in RIALC: Repertorio informatizzato dell'antica letteratura catalana (Napoli: Università di Napoli Federico II) $<$ http://www.rialc.unina.it/I7.I.htm $>$ [accessed I8-O7-20I8]

Cabré, Miriam (ed.). 2ooof. Pere Galvany 'Pus vey lo mon es vengut en tal cas', in RIALC: Repertorio informatizzato dell'antica letteratura catalana (Napoli: Università di Napoli Federico 
II) $<$ http://www.rialc.unina.it/ 7O.I.htm $>$ [accessed I8-O7-20I8]

Cabré, Miriam (ed.). 200og. Huguet del Vellat 'En breu veyrem una freyor abatre', in RIALC: Repertorio informatizzato dell'antica letteratura catalana (Napoli: Università di Napoli Federico II) $<$ http://www.rialc.unina.it/I88.I.htm $>$ [accessed I8-O7-20I8]

Cabré, Miriam (ed.). 2oooh. Andreu de Boixadors 'Pus mon cosi me trau de pressa tanta', in RIALC: Repertorio informatizzato dell'antica letteratura catalana (Napoli: Università di Napoli Federico II) <http://www.rialc.unina.it/Ig.I.htm $>$ [accessed I8-O7-2OI8]

Cabré, Miriam. 2002. 'El saber de Joan Ramon Ferrer', in Literatura i cultura a la Corona d'Aragó (s. XIII-XV), ed. by Lola Badia, Miriam Cabré and Sadurní Martí (Barcelona: Curial: Publicacions de l'Abadia de Montserrat), pp. 227-258

Cabré, Miriam; Martí, Sadurní; Navàs, Marina. 2009. 'Geografia i història de la poesia occitanocatalana del segle XIV', in Translatar i transferir. La transmissió dels textos i el saber, ed. by Anna Alberni, Lola Badia and Lluís Cabré (Santa Coloma de Queralt: Obrador Edèndum; Publicacions URV), pp. 349-76

Cluzel, Irénée. 1957-58. 'Princes et troubadous de la maison royale de Barcelone-Aragon', Boletín de la Real Academia de Buenas Letras de Barcelona, 27: 32I-73

Coll i Alentorn, Miquel (ed.). 1927-54. Ramon Muntaner Crònica, 9 vols, Col-lecció Popular Barcino, I9 (Barcelona: Barcino)

Grapí, Orland (ed). 20OI. Anònim 'Pus que.s perdet en mercaders la fes', in RIALC: Repertorio informatizzato dell'antica letteratura catalana (Napoli: Università di Napoli Federico II) $<\underline{\text { https://tinyurl.com/yagkfhm6 }}>$ [accessed 23-O5-2OI7]

Massó Torrents, Jaume. I9I4. 'Poésies en partie inédites de Johan de Castellnou et de Raimon de Cornet d'après les manuscrit de Barcelone', Annales du Midi, 26: 449-74 < https://tinyurl.com/ ygpbqjav>

Nicolau d'Olwer, Lluís. I934. 'Poesies reialistes del temps de Joan II', Estudis Universitaris Catalans, I9: 323-34

Pié, Joan. I898. 'Autos sagramentals del segle XIV', Revista de la Asociación Artístico-Arqueológica Barcelonesa, r: 673-86 and 726-44

Riquer, Isabel de (ed.). r997. Poemes catalans sobre la caiguda de Constantinoble (Barcelona: Universitat de Barcelona)

Riquer, Martín de. 1944. 'Las poesías de Pero Martines (escritor catalán del siglo Xv)', Boletín de la Real Academia de Buenas Letras de Barcelona, I7: I79-223

Riquer, Martí de (ed.). 195I. Andreu Febrer Poesies, Els Nostres Clàssics A, 68 (Barcelona: Barcino)

Riquer, Martín de. 1962. 'El poema de Arnau d'Erill contra su sobrino Fra Ramon Roger d'Erill', Boletín de la Real Academia de Buenas Letras de Barcelona, 29: 205-18

Riquer, Martí de. 1986. 'Las “coplas de la panadera” en Cataluña', in Philologia Hispaniensia in honorem Manuel Alvar, ed. by Julio Fernández-Sevilla et al. (Madrid: Gredos), III: 435-50

Rodríguez Risquete, Francisco J. 2002. 'Del cercle literari del Príncep de Viana i unes poesies satíriques del Cançoner de Saragossa', Estudi General, 22: $3_{65}$-9I $^{\prime}$ https://www.raco.cat/index. $\mathrm{php} /$ EstudiGral/article/view/43806>

Rubió i Lluch, Antoni (ed.). I908-2I. Documents per l'historia de la cultura catalana mig-eval, 2 vols 
(Barcelona: Institut d'Estudis Catalans)

Torres Amat, Fèlix. I836. Memorias para ayudar a formar un diccionario crítico de los escritores catalanes (Barcelona: J. Verdaguer)

Torró, Jaume (ed.). 2009. Sis poetes del regnat d'Alfons el Magnànim, Els Nostres Clàssics B, 29 (Barcelona: Barcino)

4.2 Altres edicions, ifonts secundàries

Asperti, Stefano. 2002. 'Testi poetici volgari di propaganda politica (secoli XII e XIII)', in La propaganda politica nel basso medievo: atti del XXXVIII Convegno Storico Internazionale, Todi 2001 (Spoleto: Centro Italiano di Studi sull'Alto Medioevo), pp. 533-59

Asperti, Stefano. 2004. 'L'eredità lirica di Bertran de Born', Cultura Neolatina, 64: 475-525

Asperti, Stefano. 2005. 'El sirventès i l'herència de Bertran de Born', Mot so razo, 4: 49-58

Cabré, Lluís (ed.). r993. Pere March Obra completa, Els Nostres Clàssics A, I32 (Barcelona: Barcino)

Cabré, Miriam. 20II. Cerverí de Girona: un trobador al servei de Pere el Gran, Blaquerna, 7 (Barcelona: Universitat de Barcelona; Palma: Universitat de les Illes Balears)

Dagenais, John. 20oo. 'Genre and Demonstrative Rhetoric: Praise and Blame in the Razos de trobar and the Doctrina de compondre dictats', in Medieval Lyric: Genres in Historical Context, ed. by William D. Paden (Urbana: University of Illinois Press), pp. 242-54

Di Girolamo, Costanzo. 199o. I trovatori (Torino: Bollati Boringhieri)

Fedi, Beatrice. 1999. 'Per un'edizione critica della prima redazzione in prosa delle Leys d'Amors', Studi Medievali, 40: 43-II8

Fedi, Beatrice. 20I7. 'Joan de Castellnou, Compendi I: osservazioni sulla struttura e fonti', in Storia, tradizione e critica dei testi: per Giuliano Tanturli, ed. by Isabella Becherucci and Concetta Bianca (Lecce: Pensa Multimedia), I: 8I-Io6

Gouiran, Gérard (ed.). 1985. L'Amour et la guerre: l'oevre de Bertran de Born (Marseille: Université de Provence)

Grifoll, Isabel. 20I7. 'Guillem de Berguedà: de la cançó satírica al sirventès', in Occitània en Catalonha: de tempses novèls, de novèlas perspectiva: actes de l'Xlèn Congrès de l'Associacion Internacionala d'Estudis Occitans, ed. by Aitor Carrera and Isabel Grifoll (Barcelona: Generalitat de Catalunya; Lhèida: Institut d'Estudis Ilerdencs), pp. 529-42 $\langle\underline{\text { https://tinyurl.com/y8fnso2v }>}$

Lausberg, Heinrich. I96o. Handbuch der literarischen Rhetorik: eine Grundlegung der Literaturwissenschaft, 2 vols (München: Max Hueber)

Marshall, J. H. (ed.). I972. The Razos de trobar of Raimon Vidal and Associated Texts (London: Oxford University Press)

Marshall, J. H. I980. 'Pour l'Étude des contrafacta dans la poésie des troubadours', Romania, IoI: 289-335 〈https://doi.org/IO.3406/roma.I980.2026>

Murphy, James Jerome. 1986. Rethoric in the Middle Ages: A History of Rethorical Theory from 
Saint Augustine to the Renaissance, Campus, 277 (Berkeley: University of California Press)

Paden, William D. 200o. 'The System of Genres in Trobadour Lyric', in MedievalLyric: Genres in Historical Context, ed. by William D. Paden (Urbana: University of Illinois Press), pp. 2 I-67

Parramon, Jordi. 1992. Repertori mètric de la poesia catalana medieval (Barcelona: Curial; Publicacions de l'Abadia de Montserrat)

Pujol, Josep. 1996. “"Psallite sapienter”: la gaia ciència en els sermons de Felip de Malla de I4I3 (edició i estudi)', Cultura Neolatina, 56: 177-250

Riquer, Martín de. 1973. 'Il significato politico del sirventese provenzale', in Concetto, storia, mitie immagini del Medio Evo, ed. by Vittore Branca (Firenze: Sansoni), pp. 287-309

Riquer, Martín de (ed.). 1975. Los trovadores, 3 vols (Barcelona: Ariel)

Rubió i Lluch, Antoni (ed.). 1908-2I. Documents per l'historia de la cultura catalana mig-eval, 2 vols (Barcelona: Institut d'Estudis Catalans)

Thiolier-Méjean, Suzanne. 1973. Les Poésies satiriques et morales des troubadours du XIIe siècle à la fin du XIII siècle (Paris: Nizet)

Torró, Jaume (ed.). 2009. Sis poetes del regnat d'Alfons el Magnànim, Els Nostres Clàssics B, 29 (Barcelona: Barcino) 